\title{
EXTRACTION KINETIC OF SOME PHENOLIC COMPOUNDS DURING CABERNET SAUVIGNON ALCOHOLIC FERMENTATION AND ANTIOXIDANT PROPERTIES OF DERIVED WINES
}

\author{
Nikolina Lisov ${ }^{1}$, Aleksandar Petrović ${ }^{1, *}$, Uroš Čakar ${ }^{2}$, Milka Jadranin ${ }^{3}$, Vele Tešević ${ }^{4}$, \\ Ljiljana Bukarica-Gojkovićs \\ ${ }^{1}$ Institute of Food Technology and Biochemistry, Faculty of Agriculture, \\ University of Belgrade, Serbia \\ ${ }^{2}$ Department of Bromatology, Faculty of Pharmacy, University of Belgrade, Serbia \\ ${ }^{3}$ Department of Chemistry, Institute of Chemistry, Technology and Metallurgy, University of Belgrade, \\ Njegoševa 12, 11001 Belgrade, Serbia \\ ${ }^{4}$ Faculty of Chemistry, University of Belgrade, Studentski trg 12-16, 11000 Belgrade, Serbia \\ ${ }^{5}$ Institute of Clinical Pharmacology and Pharmacology and Toxicology, Faculty of Medicine, \\ University of Belgrade, Serbia \\ aleksandar.petrovic@agrif.bg.ac.rs
}

In this study, we estimated the usage of Cabernet Sauvignon in microvinifications, obtaining wines with increased phenolic compound content. Kinetic extraction of phenolic compounds during alcoholic fermentation was affected by maceration time (3, 5, 7, 14 and 21 days) and the addition and kinetics of enzyme preparations (EP). The highest extraction rates were observed for catechin (EXV EP - EXV enzyme preparation and CP EP - Color plus enzyme preparation) and p-hydroxybenzoic acid (Car EP - Caractere enzyme preparation). According to extraction time of the analyzed phenolic compounds, maximal values (ellagic acid, ferulic acid, chlorogenic acid, caffeic acid, naringenin, $p$-hydroxybenzoic acid, $p$ coumaric acid, protocatechuic acid, trans-resveratrol, syringic acid, vanillin, and vanillic acid) were obtained on day 15 of maceration with addition of CP EP, with exceptions of gallic acid, catechin, and myricetin. Prolonged maceration times, up to 21 days, showed the most potent DPPH free radical scavenging activity with Car EP and the highest Ferric Reducing Ability of Plasma (FRAP) values with CP EP.

Keywords: Cabernet Sauvignon; enzyme preparations; kinetic extraction; maceration time; Ultra Performance Liquid Chromatography

\section{ЕКСТРАКЦИОНА КИНЕТИКА НА НЕКОИ ФЕНОЛНИ СОЕДИНЕНИЈА ВО ТЕКОТ НА АЛКОХОЛНАТА ФЕРМЕНТАЦИЈА НА ГРОЗЈЕ ОД СОРТАТА КАБЕРНЕ СОВИЊОН И АНТИОКСИДАНТНИ СВОЈСТВА НА ДОБИЕНИТЕ ВИНА}

Во ова истражување беше применета микровинификација на грозје од сортата каберне совињон и беа добиени вина со зголемена содржина на фенолни соединенија. Беше забележано дека кинетичката екстракција на фенолните соединенија во текот на алкохолната ферментација зависи од времето на мацерација $(3,5,7,14$ и 21 ден) и од додавањето и кинетиката на ензимските препарати (ЕР). Најголема екстракција беше забележана за катехин (EXV EP - комерцијален ензимски препарат и СР EP - ензимски препарат) и р-хидроксибензоева киселина (Car EP ензимски препарат Caractere). Во однос на влијанието на времето на екстракција врз анализираните фенолни соединенија (елагова киселина, ферулна киселина, хлорогенска киселина, кофеинска киселина, нарингенин, p-хидроксибензоева киселина, p-кумарна киселина, протокатехинска киселина, trans-ресвератрол, сирингинска киселина, ванилин и ванилна киселина), максимални вредности се добиени петнаесеттиот ден од мацерација со додавање на СР 
EP, со исклучок на гална киселина, катехин и мирицетин. Продолженото време на мацерација до 21 ден доведе до највисока антиоксидантна активност одредена со методите DPPH и FRAP, кај вината со Car EР и СР ЕР.

Клучни зборови: Каберне Совињон; ензимски препарати; кинетичка екстракција; време на мацерација; ултраефикасна течна хроматографија

\section{INTRODUCTION}

Wine composition depends on variety, climatic conditions, soil, cultivation techniques, and time of vintage during the berry ripening and winemaking process $[1,2]$. Improving the extraction of phenolic compounds from grape during winemaking is an important step in optimizing the enological process. Different winemaking techniques can be applied, such as increased maceration temperature (thermovinification), cold maceration, must or grape freezing, and addition of enzyme preparations [3]. The addition of pectolytic enzyme preparations (PEPs) is an enological practice used to reduce maceration time during vinification, yielding wines with higher values of total phenolic content (TPC), tannins and color intensity [4]. Pre-fermentative practices, such as addition of $\mathrm{SO}_{2}$ and ascorbic acid before grape crushing, also influence the content of phenolic compounds. Additionally, technological operations, such as maceration, alcoholic fermentation, inoculation of different yeast strains, $\beta$-glucosidase activity and clarification with some fining agents, also influenced the phenolic profile [5].

The most abundant non-colored phenolic compounds in grape skin are flavonols. In grape seeds, flavan-3-ol monomers, such as (+)-catechin and $(-)$-epicatechin, as well as dimers, trimmers, and polymeric forms, also called procyanidins (210 units) are present [6]. Beside their antioxidant properties, procyanidins and flavan-3-ols are mainly responsible for the astringency, bitterness and structure of wines [7]. Stilbenes (mainly resveratrol) exhibit beneficial health effects, such as cardiovascular disease prevention and antiinflammatory and anti-cancerogenic properties [8]. The polyphenolic molecules have a functional role, acting as antioxidants against free radicals, as well as a physiological role. In fact, phenolic compounds present in red wine contribute to antioxidant properties and have beneficial health effects on human organisms after consumption $[9,10]$.

A vital step during the technological process used for red wine production is PEP addition, which improves juice yield and clarification by breaking down pectin provided from the berry's structure. Breaking down skin cell walls also improves the release of intracellular pigments, which are important for the aroma and color of wines [11, 12]. The purpose of this study was to show how different technological processes, such as maceration times (3, 5, 7, 14 and 21 days) and the addition of pectolytic and glycolytic enzyme preparations (kinetic of enzyme preparations), influenced the maximal extraction of selected phenolic compounds, extraction rate, and antioxidant properties of Cabernet Sauvignon wines.

\section{MATERIALS AND METHODS}

\subsection{Chemicals}

Acetonitrile, methanol and formic acid were High Performance Liquid Chromatography grade (HPLC) and purchased from Merck (Darmstadt, Germany). Ultra-pure water (MicroPure water purification system, $0.055 \mu \mathrm{S} / \mathrm{cm}$; Thermofisher TKA, Germany) was used for solid phase extraction (SPE) and liquid chromatography/mass spectrometry (UPLC-MS/MS) analyses. The Oasis HLB bcc/200 $\mu \mathrm{m}$ SPE cartridges (Waters, Milford, MA, USA), were used for SPE of samples. Phenolic compound standards were purchased from SigmaAldrich (Steinheim, Germany) and Fluka (Buch, Switzerland). Trolox (6-hydroxy-2,5,7,8-tetramethylchroman-2-carboxylic acid), 2,2-azino-bis(3ethylbenzothiazoline-6-sulfonic acid) (ABTS), 2,2diphenyl-1-picrylhydrazyl (DPPH), and potassium persulfate were purchased from Sigma-Aldrich (Steinheim, Germany). Folin-Ciocalteu (FC) reagent was obtained from Merck (Darmstadt, Germany). TPTZ (2,4,6-trypyridyl-s-triazine) was purchased from Fluka Analytical (Switzerland).

\subsection{Plant material}

Wines were made at the oenological station of the Faculty of Agriculture, Radmilovac, in Belgrade, Serbia, from the grape variety of Cabernet Sauvignon. The experimental vineyard was built in 2003 and includes growing grapes in rows with a formed Single Guyot training system. The number of fruiting buds per cane was eight. Spacing be- 
tween rows was $3 \mathrm{~m}$, with $1 \mathrm{~m}$ between vines in the row. The row directions were North-EastSouth-West, and the average yield of grapes per vine was 2 kilos. Grapes were harvested at technological maturity (phytosanitary health $100 \%$ ). The sugar content in must was $23 \%$, while the total titratable acid was $6.8 \mathrm{~g} / \mathrm{l}$, expressed as tartaric acid. Sugar content of grape must was analyzed using the Oechsle tester, an apparatus for measuring grape must density, and the titratable acid content was determined by a volumetric method.

\subsection{Wine making}

After removing grape berries from stems, berries were crushed automatically, and $10 \mathrm{~g}$ of potassium metabisulfite $\left(\mathrm{K}_{2} \mathrm{~S}_{2} \mathrm{O}_{5}\right)$ was added to grape must per $100 \mathrm{~kg}$ of crushed grapes. About 100 kilos of grapes were required for all experiments. Microvinification, which included alcohol fermentation and maceration, was carried out at $25 \pm 3{ }^{\circ} \mathrm{C}$, using a watts with pigéage system (mechanically punching down the solids into the liquid) twice a day. Wine yeast, Saccharomyces cerevisiae (BDX, Lallemand, Canada; $20 \mathrm{~g} / \mathrm{hl}$ ), was added. PEP Color Plus (CP; Enartis, Italy), enzyme preparation Caractere (Car; Enartis, Italy) with pectolytic, hemicellulase and $\beta$-glycosidase activity, and EXV (commercial enzyme preparation; Lallemand, Canada) with pectolytic activity were added, as well ( $2 \mathrm{~g} / \mathrm{hl}$ each). Five skin maceration periods were applied at 3, 5, 7, 14 and 21 days. The liquid portion was separated after the five maceration periods, and alcoholic fermentation of the liquid was conducted after separation of solids (seeds and skin). After racking twice, wines were bottled $(750 \mathrm{ml}$ bottles) and stored until analysis. The assay included a total of 16 wine samples (triplicate), including a control sample of wine fermented without pomace (separated immediately after crushing).

\section{4. $S P E$}

Aiming to decrease the matrix influence during phenolic identification and quantification, SPE was performed, as described by Ljekočević et al. [13]. This extraction was performed on a vacuum device (SPE Vacuum Manifold Baker SPE12G) using Oasis HLB bcc/200 $\mu \mathrm{m}$ cartridges. The cartridge was conditioned with $5 \mathrm{ml}$ of methanol, followed by $5 \mathrm{ml}$ of distilled water. A wine sample (5 $\mathrm{ml}$ ) was passed through the cartridge, washed with $2 \mathrm{ml}$ of water, and eluted with $2 \mathrm{ml}$ of methanol.
The samples were collected and analyzed by UPLC/MS-MS.

\subsection{UPLC-MS/MS}

UPLC-MS/MS analysis was performed using a Waters Acquity UPLC H-Class System (Waters, Milford, MA, USA). Separation was achieved on the Acquity UPLC BEH $\mathrm{C}_{18}$ column $(50 \times 2.1$ $\mathrm{mm} ; 1.7 \mu \mathrm{m})$. The mobile phase consisted of $0.2 \%$ formic acid in water (solvent $\mathrm{A}$ ) and acetonitrile (solvent B). The following gradient was used: $0-1$ min, $1 \% \mathrm{~B}$; 1-1.5 min, 1-3\% B; 1.5-13.5 min, 3$32 \% \mathrm{~B} ; 13.5-18.5 \mathrm{~min}, 32-60 \% \mathrm{~B} ; 18.5-20.5$ min, 60-99 \% B; 20.5-24.9 min, $99 \%$ B; 24.9-25 min, 99-1 \% B; and 25-30 min, $1 \%$ B. During analysis, the column was kept at $45^{\circ} \mathrm{C}$, while flow rate and injection volume were $0.40 \mathrm{ml} / \mathrm{min}$ and 10 $\mu 1$, respectively. The IntelliStart feature of MassLynx V4.1 (Waters, Milford, MA, USA; 2005), by direct injection of methanolic standard solution into the mass spectrometer, was used to obtain optimized parameters for quantification of investigated components, including ionization mode, cone voltage, collision energy, and characteristic transitions (MRM, multiple reaction monitoring; Table 1). The electrospray source was operated under conditions described by Ljekočević et al. [13] with slight modification. Argon was used as the collision gas, and system operation (data collection and processing) was controlled by MassLynx V 4.1 software (Waters, Milford, MA, USA, 2005). To identify and determine the content of selected phenolic compounds (ellagic acid, ferulic acid, chlorogenic acid, caffeic acid, naringenin, $p$-hydroxybenzoic acid, $p$-coumaric acid, protocatechuic acid, trans-resveratrol, syringic acid, vanillin, vanillic acid, gallic acid, catechin and myricetin) in wine samples, methanolic solutions of these compounds with concentrations of $0.001,0.002,0.005,0.01$, $0.02,0.05,0.1,0.2,0.5,1,2,5,10,20$ and 50 $\mu \mathrm{g} / \mathrm{ml}$ were recorded under the same conditions used to measure the samples.

Phenolic compounds were identified by comparison of their retention times $\left(t_{\mathrm{R}}\right)$ and mass spectra (MRM - Multiple reaction monitoring of transitions in electrospray ionisation ESI- or ESI+ modes) with relevant standards. Based on calibration curves, which were constructed using the dependence of signal surface area for the appropriate substance transition on the substance concentration in the standard solution, the contents of tested phenolic compounds in the analyzed wine samples were calculated. 


\subsection{Ferric reducing ability of plasma (FRAP)}

Redox potentials of wine samples were determined using the FRAP test [14]. The FRAP assay depends on the conversion of the ferric tripyridyltriazine (Fe(III)-TPTZ) complex to ferrous tripyridyltriazine ( $\mathrm{Fe}(\mathrm{II})$-TPTZ) by a reductant at low pH. Fe(II)-TPTZ had an intense blue color and was monitored at $593 \mathrm{~nm}$. The FRAP working solution was prepared as a mixture with acetate buffer $(\mathrm{pH}$ = 3.6), TPTZ solution, and $\mathrm{FeCl}_{3} \cdot 6 \mathrm{H}_{2} \mathrm{O}$ solution (10:1:1). Then, $75 \mu \mathrm{l}$ of appropriately diluted wine samples were mixed with $2.25 \mathrm{ml}$ of FRAP working solution. After reacting for $6 \mathrm{~min}$ at $37{ }^{\circ} \mathrm{C}$, the absorbance was measured at $593 \mathrm{~nm}$ using a Ultraviolet-Visible double beam spectrophotometer (HALO DB-20; Dynamica GmbH). Aqueous solutions of known $\mathrm{Fe}(\mathrm{II})$ concentrations were used for calibration (100-1000 $\mu \mathrm{mol} / \mathrm{l})$, and the obtained results were expressed in $\mathrm{mmol} / \mathrm{l} \mathrm{Fe}^{2+}$.

\section{7. $D P P H$ free radical scavenging activity}

Antioxidant potential (AOP) or free radical scavenging activities were thoroughly studied, and various experimental assays were developed for their evaluation. The DPPH assay measures the intrinsic ability of a compound to transfer a hydrogen atom or electron to the DPPH radical, which results in the formation of colorless $\mathrm{DPPH}_{2}$, with a corresponding decrease in DPPH concentration [15]. Hydrogen atom transfer from non-ionized antioxidants is the other mechanism involved in the reaction of polyphenolic antioxidants with free radicals $[16,17]$. This method involves a stable radical molecule DPPH, and results are expressed as mean scavenging concentration, $\mathrm{IC}_{50}$ (inhibition concentration), representing the amount of antioxidant necessary to decrease the DPPH radical concentration by $50 \%$. Prior to testing, wine samples were diluted with water in rations from 1:2 to $1: 20$, depending on antioxidant activity strength of the wine samples. Experimental findings demonstrated that this range exhibits a linear relationship between absorbance and concentration. Each sample was prepared with five dilutions, in triplicate. The $\mathrm{IC}_{50}$ value was obtained from a chart, where the inhibition percentage was presented against concentration $I(\%)=f(c)$. Percentage of DPPH radical inhibition was calculated according to Eq. 1:

$$
I(\%)=100\left(\left(A_{\text {blank }}-A_{\text {sample }}\right) / A_{\text {blank }}\right) \quad \text { Eq. } 1
$$

where $A_{\text {blank }}$ is the absorbance of DPPH with ethanol, while $A_{\text {sample }}$ describes the absorbance of DPPH after reaction with the tested wine sample. The absorbance was read after $40 \mathrm{~min}$ at $525 \mathrm{~nm}$, against ethanol. The results were expressed as the reciprocal value $I(\%)$ multiplied by 100 [18].

Table 1 Parameters for identification and quantification of selected compounds
in Cabernet Sauvignon wine samples

\begin{tabular}{|c|c|c|c|c|c|c|c|}
\hline $\begin{array}{l}\text { Phenolic } \\
\text { Compound }\end{array}$ & $\begin{array}{l}\text { Molecular } \\
\text { formula }\end{array}$ & $\begin{array}{l}\text { Molecular } \\
\text { mass }\end{array}$ & $\begin{array}{c}t_{\mathrm{R}} \\
(\mathrm{min})\end{array}$ & $\begin{array}{c}\text { ESI } \\
\text { mode }\end{array}$ & $\underset{\text { MRM }}{\text { transition }}$ & $\begin{array}{c}\text { Cone } \\
\text { voltage } \\
(\mathrm{V}) \\
\end{array}$ & $\begin{array}{c}\text { Collision } \\
\text { energy } \\
(\mathrm{eV})\end{array}$ \\
\hline Ellagic acid & $\mathrm{C}_{14} \mathrm{H}_{6} \mathrm{O}_{8}$ & 302 & 3.8 & + & $303 \rightarrow 89$ & 50 & 56 \\
\hline Ferulic acid & $\mathrm{C}_{10} \mathrm{H}_{10} \mathrm{O}_{4}$ & 194 & 3.8 & + & $195 \rightarrow 145$ & 20 & 16 \\
\hline Gallic acid & $\mathrm{C}_{7} \mathrm{H}_{6} \mathrm{O}_{5}$ & 170 & 0.8 & - & $169 \rightarrow 125$ & 30 & 20 \\
\hline Chlorogenic acid & $\mathrm{C}_{16} \mathrm{H}_{18} \mathrm{O}_{9}$ & 354 & 2.6 & + & $355 \rightarrow 163$ & 20 & 12 \\
\hline Caffeic acid & $\mathrm{C}_{9} \mathrm{H}_{8} \mathrm{O}_{4}$ & 180 & 2.8 & - & $179 \rightarrow 135$ & 30 & 20 \\
\hline Catechin & $\mathrm{C}_{15} \mathrm{H}_{14} \mathrm{O}_{6}$ & 290 & 2.5 & + & $291 \rightarrow 139$ & 26 & 20 \\
\hline Myricetin & $\mathrm{C}_{15} \mathrm{H}_{10} \mathrm{O}_{8}$ & 318 & 4.6 & - & $317 \rightarrow 151$ & 48 & 24 \\
\hline Naringenin & $\mathrm{C}_{15} \mathrm{H}_{12} \mathrm{O}_{5}$ & 272 & 6.0 & - & $271 \rightarrow 151$ & 24 & 24 \\
\hline $\begin{array}{l}p \text {-Hydroxybenzoic } \\
\text { acid }\end{array}$ & $\mathrm{C}_{7} \mathrm{H}_{6} \mathrm{O}_{3}$ & 138 & 2.1 & - & $137 \rightarrow 93$ & 30 & 20 \\
\hline p-Coumaric acid & $\mathrm{C}_{9} \mathrm{H}_{8} \mathrm{O}_{3}$ & 164 & 3.4 & - & $163 \rightarrow 119$ & 15 & 30 \\
\hline Protocatechuic acid & $\mathrm{C}_{7} \mathrm{H}_{6} \mathrm{O}_{4}$ & 154 & 1.3 & - & $153 \rightarrow 109$ & 30 & 20 \\
\hline trans-Resveratrol & $\mathrm{C}_{14} \mathrm{H}_{12} \mathrm{O}_{3}$ & 228 & 4.8 & + & $229 \rightarrow 107$ & 34 & 24 \\
\hline Syringic acid & $\mathrm{C}_{9} \mathrm{H}_{10} \mathrm{O}_{5}$ & 198 & 2.9 & - & $197 \rightarrow 121$ & 28 & 18 \\
\hline Vanillin & $\mathrm{C}_{8} \mathrm{H}_{8} \mathrm{O}_{3}$ & 152 & 3.3 & - & $151 \rightarrow 136$ & 30 & 14 \\
\hline Vanillic acid & $\mathrm{C}_{8} \mathrm{H}_{8} \mathrm{O}_{4}$ & 168 & 2.7 & + & $169 \rightarrow 93$ & 15 & 30 \\
\hline
\end{tabular}




\subsection{Trolox equivalent antioxidant capacity (TEAC)}

The TEAC test is based on reduction of the ABTS cation radical and was carried out according to the procedure described by Re et al. [19] with slight modifications. Briefly, ABTS radical cations were generated by reacting aqueous ABTS with potassium persulfate and maintaining the mixture in the dark at room temperature for at least $12 \mathrm{~h}$ before use. Afterwards, the absorbance of the ABTS solution was set to $0.70 \pm 0.02$ at $734 \mathrm{~nm}$ by adding phosphate buffer. Then, $30 \mu$ of appropriately diluted wine samples were mixed with $3 \mathrm{~mL}$ of ABTS solution. After reacting for $7 \mathrm{~min}$, the absorbance was measured at $734 \mathrm{~nm}$ using a UVVis double beam spectrophotometer (HALO DB20; Dynamica $\mathrm{GmbH}$ ). Antioxidant activity was calculated on the basis of decreasing absorbance and expressed as mmol of Trolox equivalents per liter of wine (Trolox mmol/l).

\section{9. $T P C$}

The TPCs of wine samples were estimated by the FC method using gallic acid as a standard [20]. Briefly, $1 \mathrm{ml}$ of diluted wine (1:5), mixed with $75 \mathrm{ml}$ of distilled water, was added in a volumetric flask $(100 \mathrm{ml})$. After $3 \mathrm{~min}, 5 \mathrm{ml}$ of FC reagent was added. The contents were mixed by manual shaking for 15-20 s.

Then, $10 \mathrm{ml}$ of saturated sodium carbonate solution was added, followed by filling the volumetric flask with distilled water to the mark. The reaction mixture was incubated at room temperature for $60 \mathrm{~min}$, and its absorbance was measured at $720 \mathrm{~nm}$ using a UV-Vis double beam spectrophotometer (HALO DB-20; Dynamica GmbH). The TPC was determined using a calibration curve prepared with a gallic acid standard as a reference. The values were reported as $\mathrm{mg}$ of gallic acid equivalent (GAE), referring to the gallic acid standard curve, and the results were expressed in $\mathrm{mg}$ of GAEs per liter of wine (mg GAE/L).

\subsection{Total corrected FRAP}

One of the most important agents added to wines, to prevent oxidative processes, is $\mathrm{SO}_{2}$ (sulfur dioxide). As well as having antioxidant activity, $\mathrm{SO}_{2}$ serves as an antimicrobial agent [21]. The influence of free $\mathrm{SO}_{2}$ on total antioxidant activity was eliminated by forming a corrected curve (FRAP corrected). Model solutions with free $\mathrm{SO}_{2}$ concentrations from 2 to $7 \mathrm{~g} / \mathrm{hl}$ were prepared by the addition of $\mathrm{K}_{2} \mathrm{~S}_{2} \mathrm{O}_{5}$. The $\mathrm{pH}$ value of initial solu- tion was 3.5, adjusted by the addition of tartaric acid. $\mathrm{K}_{2} \mathrm{~S}_{2} \mathrm{O}_{5}$ was added in amounts necessary to provide free $\mathrm{SO}_{2}$ concentrations from 10 to 35 $\mathrm{mg} / \mathrm{l}$. Iodometric titrations, according to Ripper, were used to estimate the free $\mathrm{SO}_{2}$ concentrations, both in model solutions and wine samples [20]. Model solutions were analyzed by the FRAP method, and obtained results were expressed as FRAP $_{\text {model }}$ solution. The corrected FRAP value $\left(\mathrm{FRAP}_{\text {corrected }}\right)$ was obtained from the difference between the FRAP values of the wine samples with free $\mathrm{SO}_{2}\left(\mathrm{FRAP}_{\text {total }}\right)$ and model solution values with the same $\mathrm{SO}_{2}$ concentration (FRAP ${ }_{\text {model solution }}$ ).

\subsection{Statistical analysis}

Statistical analysis was conducted using SPSS Statistical V20.0 software (IBM, Chicago, IL, USA; 2014), one sample T-test, paired samples T-test and principal component analysis (PCA). Linear regression correlation analysis was obtained with Origin Pro 8 (OriginLab, Northampton, MA, USA; 2008).

\section{RESULTS AND DISCUSSION}

\subsection{Influence of maceration time and enzyme preparations on the phenolic profile of wine}

The duration of maceration time during microvinification is vitally important for the extraction of phenolic compounds in wine. The addition of three enzyme preparations (EXV, $\mathrm{CP}$ and Car) during maceration time was analyzed, with an additional focus on kinetic extraction of certain quantified phenolic compounds. Prolonged maceration time has been shown to increase the content of certain phenolic compounds (Figs. 1-3) [22]. The concentration of gallic acid increased during alcoholic fermentation and maceration, until day 20 $(34.92 \pm 1.35 \mathrm{mg} / \mathrm{l}$; Figs. 1C, 2C and 3C). Generally, the TPC increased with prolonged maceration time, reaching a maximum value $(854.9 \mathrm{mg} / \mathrm{l})$ on day 90 of post-fermentation maceration. However, a prior study compared kinetic extraction of some phenolic compounds until day 20 , and results were in accordance with our findings [23]. Obtained results for protocatechuic, $p$-coumaric, syringic and vanillic acids showed maximum extraction between days 10 and 16 (Figs. 1A, B and C, 2A, B and $\mathrm{C}$, and $3 \mathrm{~A}, \mathrm{~B}$ and $\mathrm{C}$ ). This extraction was much more efficient compared to day 20 for the same compounds, as reported by Francesca et al. [23], while caffeic acid content increased exponentially, similar to our results (Figs. 1A, 2A and 3A). 
According to other studies, concentrations of naringenin, trans-resveratrol and catechin showed regular trends, increasing for all 20 days of maceration [23-25]. However, contrary to literature data, our results for the same three phenolic compounds showed exponentially increasing concentrations

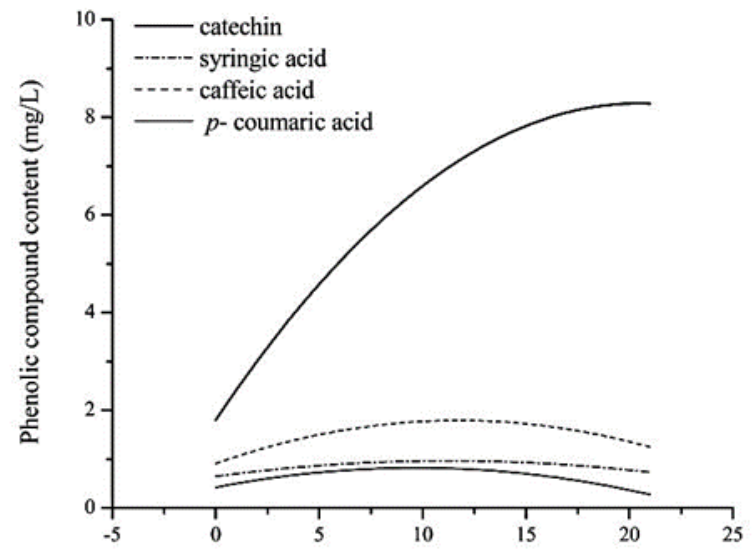

A

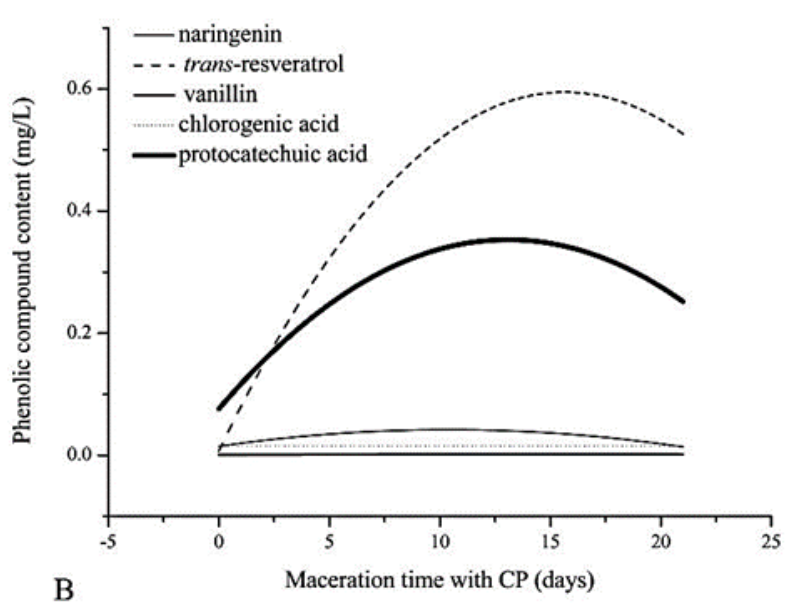

B

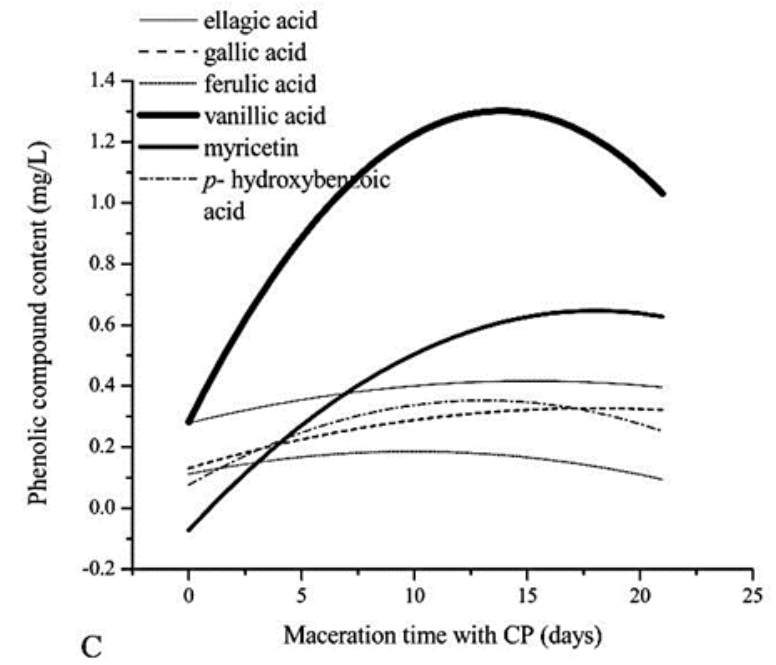

Fig. 1. Extraction dynamics of certain phenolic compounds with $\mathrm{CP}$ with extraction maxima obtained a few days earlier (Figs. 1A and B, 2A and B, and 3A and B). This difference can be explained by the use of different enzyme preparations during maceration, which can accelerate extraction of phenolic compounds [26].
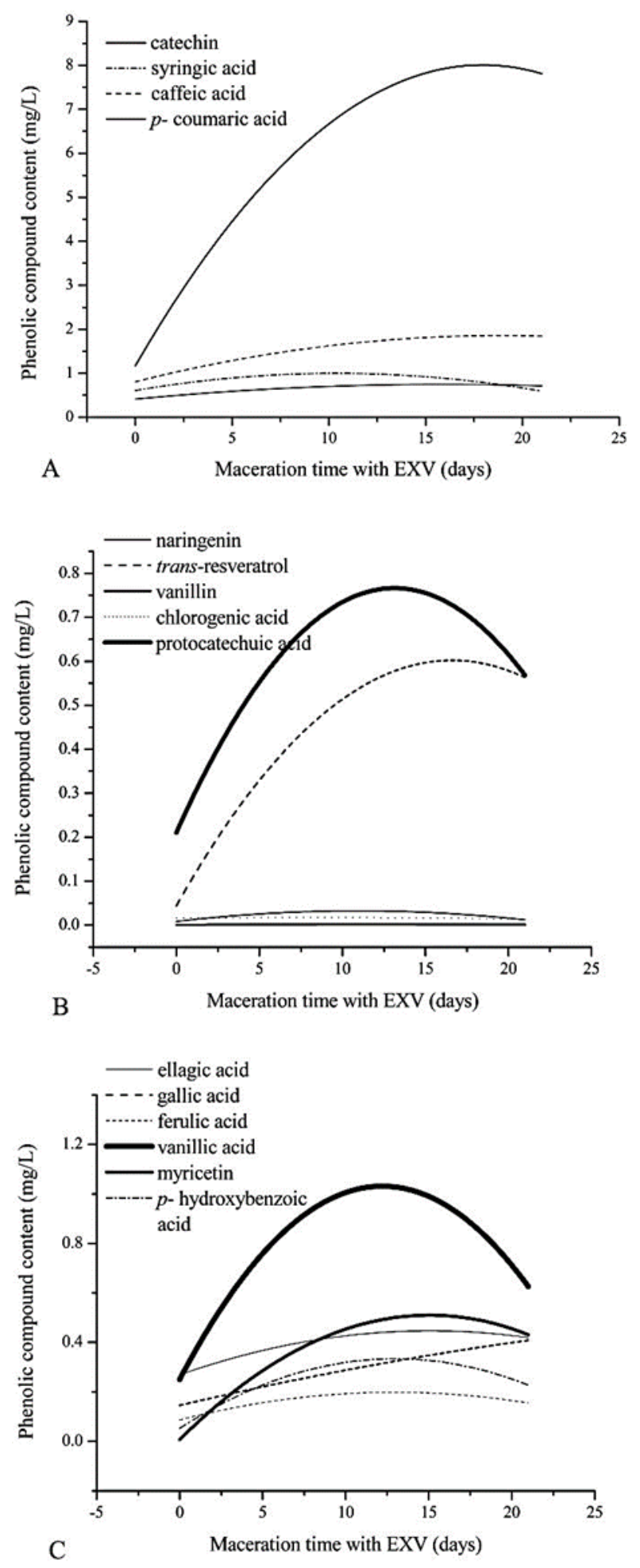

Fig. 2. Extraction dynamics of certain phenolic compounds with EXV 


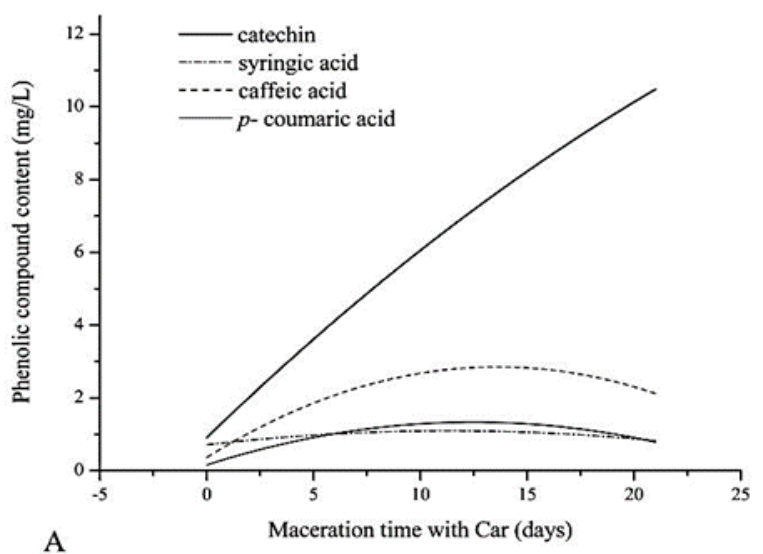

A
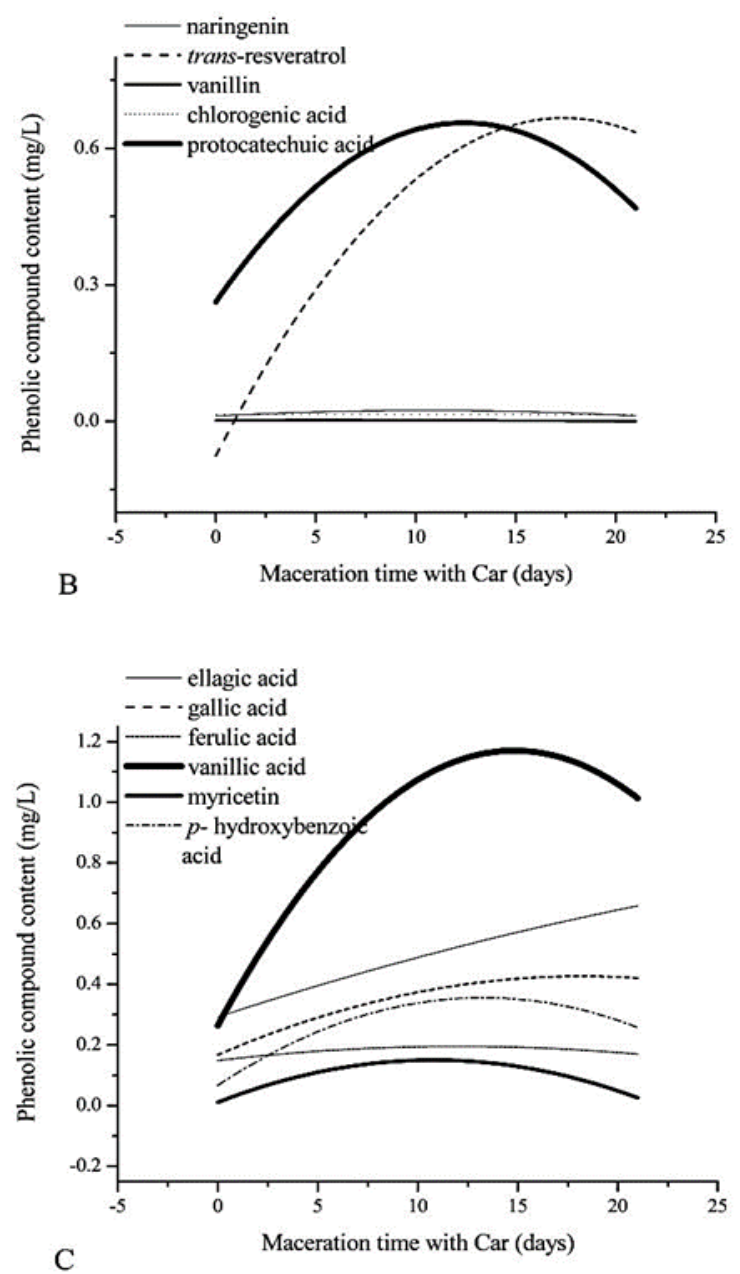

Fig. 3. Extraction dynamics of certain phenolic compounds with Car

Application of enzyme preparation during microvinification increased the extraction of phenolic compounds and significantly influenced biological activity of the wines [27].

Extraction maximum of certain phenolic compounds was evaluated over 21 days of maceration with three types of enzyme preparations.
Comparing the three different enzyme preparations, extraction maxima for naringenin (day 10) and $p$-hydroxybenzoic acid (day 13) occurred on the same day for all three preparations (Table 2). For other analyzed phenolic compounds, extraction maxima were obtained on different days with various extraction rates (Table 2). Different extraction maxima for the phenolic compounds depended on the technological process (temperature, $\mathrm{pH}$, irrigation of grape must). In fact, seed flavan-3-ols were the last extracted compounds, since they are protected with a cuticle layer (composed of waxes), which is disrupted once an appropriate content of alcohol is formed, allowing their release from the seeds [28]. Longer skin contact leads to higher extraction of phenolic compounds, especially at the beginning of maceration when anthocyanins and flavonols are the first compounds extracted from the skins, while extraction of seed flavan-3-ols occurs in the later days [29]. Maximum extraction for trans-resveratrol occurred around day 15 of maceration, which is in accordance with results from Lingua et al. [30], where the content of the same compound was significantly increased $(p<0.0001)$ in Cabernet Sauvignon. During alcoholic fermentation, trans-resveratrol was extracted from skin, while in the later steps of winemaking, it underwent changes altering its content, which decreased after day 15 of maceration [31]. Importantly, the extraction rate of different phenolic compounds from must to wine depends on maceration conditions, such as temperature, enzyme, yeast, etc. [32, 33 ], and further, proper vineyard management influences the content of flavonols in grapes [34].

In order separate the fifteen phenolic compounds quantified during microvinification conducted with enzyme preparations, PCA statistical analysis was applied. This method reduces a large number of data sets (single compounds) by adding factors that have their own factor loadings, containing properties of the reduced elements. The parameters for PCA statistical analysis were equamax rotation, Kaiser-Meyer-Olkin criterion 0.695, and Bartlett's test of sphericity with statistical significance $(p<0.05)$, while factor loadings below 0.3 were excluded. Equamax rotation showed distinctly better separation of components than quartimax and varimax. The selected rotation most clearly separated variables, polyphenols, in the factor loading function. Four components were selected (84.091 variability, cumulatively) and were proven using the Cattell criterion. Briefly, two groups were clearly distinguished. The first one contained derivatives of cinnamic acid and corresponded to component 2 (Fig. 4). The second group included different groups of phenolic com- 
pounds, such as stilbenes (trans-resveratrol), flavan-3-ols (catechin), derivatives of hydroxybenzoic acid (vanillin, $p$-hydroxybenzoic acid, proto- catechuic acid, syringic acid, vanillic acid and gallic acid), flavonols (myricetin) and flavanone (naringenin), as shown in Figure 4.

Table 2

Days of maceration with maximal extraction amounts of certain phenolic compounds and corresponding extraction rates

\begin{tabular}{|c|c|c|c|c|c|c|c|c|c|}
\hline $\begin{array}{l}\text { Phenolic } \\
\text { compound }\end{array}$ & $\begin{array}{c}\text { Time } \\
\text { of max } \\
\text { extraction } \\
\text { (day) }\end{array}$ & $\begin{array}{c}\text { Amount } \\
\text { of max } \\
\text { extraction } \\
(\mathrm{mg} / \mathrm{l})\end{array}$ & $\begin{array}{c}\text { Extraction } \\
\text { rate } \\
\text { (mg/day) } \\
\end{array}$ & $\begin{array}{c}\text { Time } \\
\text { of max } \\
\text { extraction } \\
\text { (day) }\end{array}$ & $\begin{array}{c}\text { Amount } \\
\text { of max } \\
\text { extraction } \\
(\mathrm{mg} / \mathrm{l})\end{array}$ & $\begin{array}{l}\text { Extraction } \\
\text { rate } \\
(\mathrm{mg} / \text { day })\end{array}$ & $\begin{array}{c}\text { Time } \\
\text { of max } \\
\text { extraction } \\
\text { (day) }\end{array}$ & $\begin{array}{c}\text { Amount } \\
\text { of max } \\
\text { extraction } \\
(\mathrm{mg} / \mathrm{l})\end{array}$ & $\begin{array}{l}\text { Extraction } \\
\text { rate } \\
\text { (mg/day) }\end{array}$ \\
\hline $\begin{array}{c}\text { Enzyme } \\
\text { preparation }\end{array}$ & & EXV & & & Car & & & $\mathrm{CP}$ & \\
\hline Ellagic acid & 15. & 0.4467 & 0.00156 & 21. & 0.6584 & 0.00039 & 15. & 0.4166 & 0.00119 \\
\hline Ferulic acid & 12. & 0.1983 & 0.00133 & 12. & 0.1951 & 0.00063 & 10. & 0.1857 & 0.00149 \\
\hline Gallic acid & 21. & 0.4083 & 0.00031 & 18. & 0.4264 & 0.03350 & 18. & 0.3274 & 0.00121 \\
\hline $\begin{array}{l}\text { Chlorogenic } \\
\text { acid }\end{array}$ & 8. & 0.0175 & 0.00010 & 9. & 0.0155 & 0.00002 & 13. & 0.0154 & 0.00001 \\
\hline Caffeic acid & 18. & 1.8570 & 0.00590 & 13. & 2.8510 & 0.02660 & 12. & 1.7930 & 0.01280 \\
\hline Catechin & 18. & 8.0070 & 0.04240 & 21. & 10.476 & 0.01070 & 20. & 8.2850 & 0.03120 \\
\hline Myricetin & 15. & 0.5100 & 0.00454 & 10. & 0.2860 & 0.00239 & 18. & 0.6460 & 0.00443 \\
\hline Naringenin & 10. & 0.0327 & 0.00022 & 10. & 0.0300 & 0.00022 & 10. & 0.0420 & 0.00050 \\
\hline $\begin{array}{l}p \text {-Hydroxy- } \\
\text { benzoic acid }\end{array}$ & 13. & 0.3340 & 0.00330 & 13. & 0.3556 & 0.04540 & 13. & 0.3530 & 0.00322 \\
\hline $\begin{array}{l}p \text {-Coumaric } \\
\text { acid }\end{array}$ & 16. & 0.7483 & 0.00260 & 12. & 1.3350 & 0.01510 & 10. & 0.9155 & 0.00851 \\
\hline $\begin{array}{l}\text { Protocatechuic } \\
\text { acid }\end{array}$ & 13. & 0.7663 & 0.00630 & 12. & 0.6560 & 0.00515 & 13. & 0.9300 & 0.00990 \\
\hline $\begin{array}{l}\text { trans-Resve- } \\
\text { ratrol }\end{array}$ & 16. & 0.6021 & 0.00400 & 17. & 0.6660 & 0.00490 & 15. & 0.5950 & 0.00481 \\
\hline Syringic acid & 10. & 0.9986 & 0.00710 & 11. & 1.0960 & 0.00590 & 11. & 1.0740 & 0.00726 \\
\hline Vanillin & 11. & 0.0022 & 0.00003 & 10. & 0.0014 & 0.00002 & 13. & 0.0017 & 0.00008 \\
\hline Vanillic acid & 12. & 1.0311 & 0.01040 & 14. & 1.1703 & 0.00825 & 13. & 1.1310 & 0.01062 \\
\hline
\end{tabular}

\subsection{Influence of maceration time and enzyme preparations on antiradical and antioxidant properties of wine}

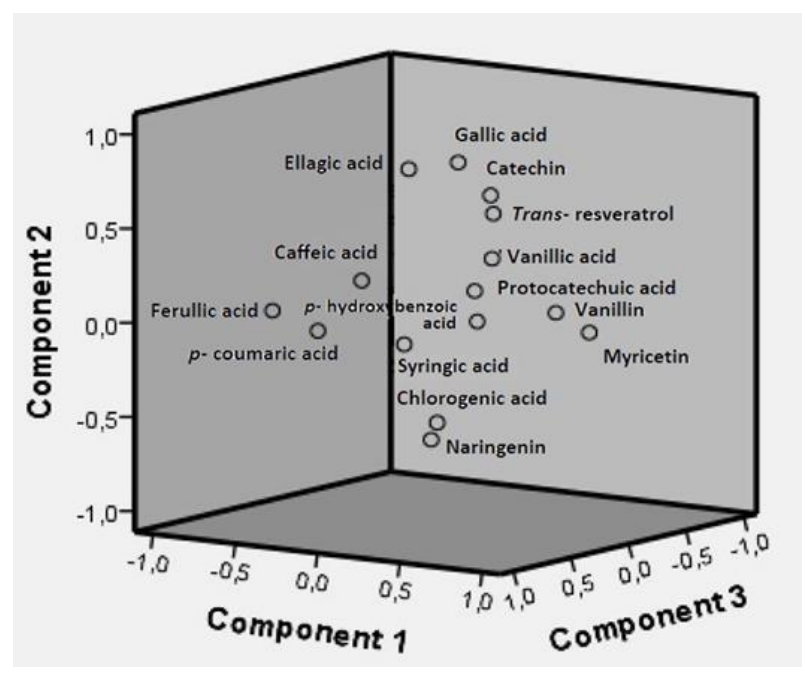

Fig. 4. Component plot analysis of principal components
In order to estimate the influence of different enzyme preparations on antiradical and antioxidant properties of wine samples, the one sample T-test was applied. The addition of enzyme preparations during maceration effected DPPH free radicalscavenging activity and antioxidant properties (FRAP and TEAC assays) of all wine samples ( $\mathrm{p}<0.01)$. To evaluate the influence of free $\mathrm{SO}_{2}$ on the FRAP values of analyzed wines, a paired sample T-test was applied. Statistically significant differences $(p<0.01)$ between $\mathrm{FRAP}_{\text {total }}$ and $\mathrm{FRAP}_{\text {corrected values of wine }}$ samples with addition of enzyme preparations $\mathrm{CP}$, EXV, and Car were revealed (Figs. 5C, D and E). Further, the antiradical and antioxidant activity of wine samples produced with the addition of different enzyme preparations (EXV, CP and Car) showed 
statistically significant differences $(p<0.01)$, consistent with literature data [35].

During prolonged maceration, an enrichment of the phenolic fraction (mainly flavan-3-ols and procyanidins) occurs, which are the most potent antioxidants, and this observation could explain the significant increase in antioxidant capacity of Cabernet Sauvignon with prolonged skin maceration. Higher alcohol levels improved the extraction of phenolic compounds, leading to better antioxidant capacities in the wine samples [36], and higher TPC values influenced the increase of antioxidant properties [32].

Differences in concentrations of certain phenolic compounds were related to the different anti-
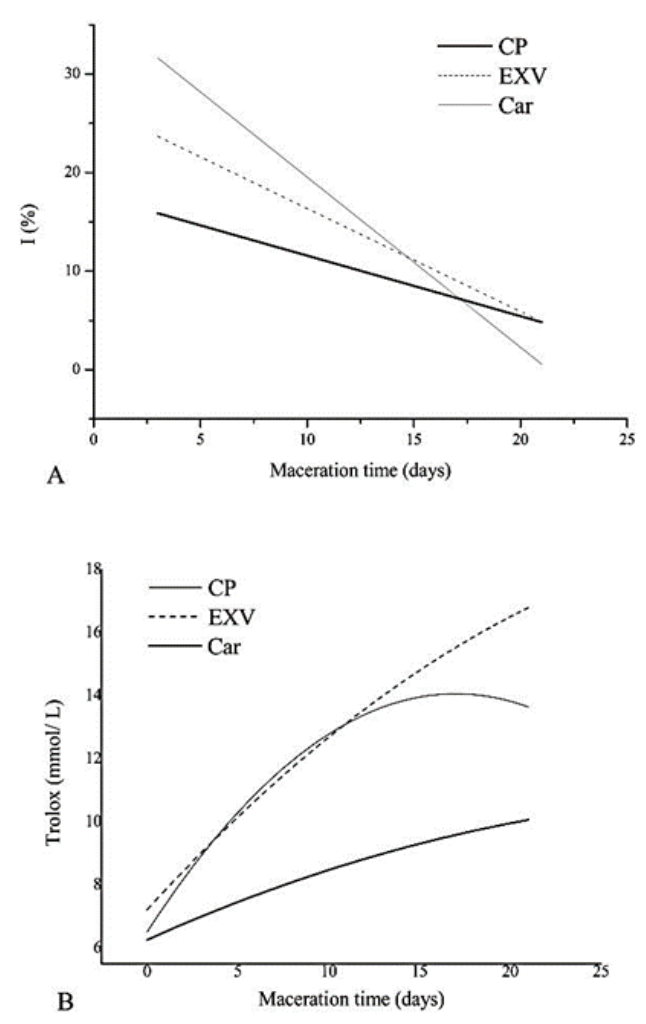

oxidant capacities of the wines. In some research, varieties, such as Merlot or Cabernet Sauvignon, have high concentrations of catechin and higher antioxidant capacity values. In contrast, other varieties, such as Sangiovese, showed lower values of catechin and, consequently, lower antioxidant capacities [37]. Our results indicated that the dominant phenolic compound was catechin and its content increased during maceration, consequently, increasing antioxidant capacities. Antioxidant capacities of all wine samples increased linearly for the FRAP assay and DPPH free radical scavenging activity (Figs. 5A, C, D and E). However, the TEAC assay increased exponentially (Fig. 5B).
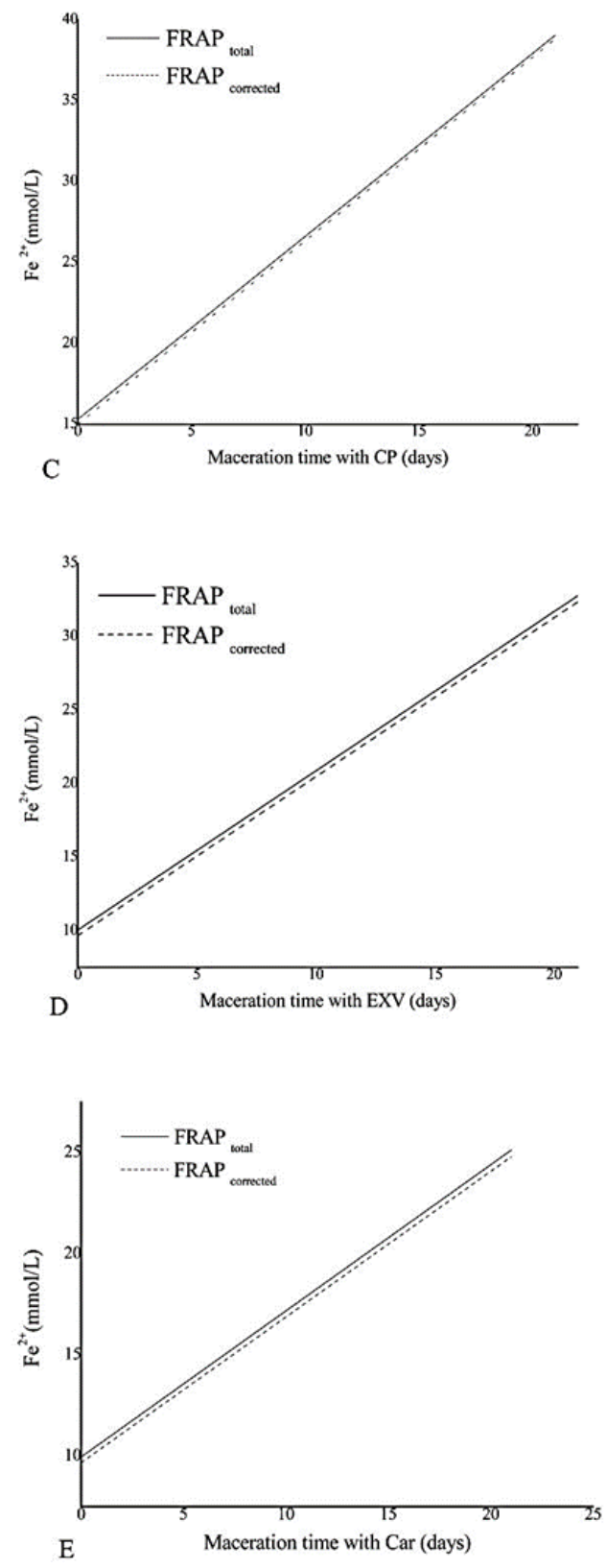

Fig. 5. DPPH free radical scavenging activity of wine samples (A) and TEAC values (B) over 21 days of maceration with three different enzymes. The influence of $\mathrm{SO}_{2}$ on total antioxidant activity, measured by the FRAP assay, is shown in (C), (D) and (E). 
The lowest antioxidant capacity measured by the FRAP assay was observed on day 3 of maceration with Car $\left(12 \pm 1.17 \mathrm{mmol} / \mathrm{l} \mathrm{Fe}^{2+}\right.$; Fig. 5E) and the highest was observed on day 21 with $\mathrm{CP}$ $\left(36 \pm 2.56 \mathrm{mmol} / \mathrm{l} \mathrm{Fe}^{2+}\right.$; Fig. $\left.5 \mathrm{C}\right)$. The results obtained by the FRAP assay for all enzyme preparations showed statistically significant differences between the control sample and sample obtained after 21 days of maceration. Also, there were statistically significant differences between results of the FRAP test for samples with and without correction for free $\mathrm{SO}_{2}$ (Figs. 5C, D and E). The lowest DPPH free radical scavenging activity was observed on day 3 with Car (40.66\%), and the highest was measured on day 21 for the wine sample with the same enzyme preparation (5.8 \%; Fig. 5A). Statistically significant differences were observed between antioxidant capacities of the control sample and those at days 3 to 21 for all three enzyme preparations measured by DPPH free radical scavenging activity $(p<0.05)$. For samples with other enzyme preparations (EXV and $\mathrm{CP}$ ), the highest antioxidant capacities were also achieved on day 21 (7.33\% and $6.48 \%$; Fig. 5A). The antioxidant capacity, measured by TEAC method, showed the highest value on day $21(17.20 \pm 1.57$ Trolox mmol/l) with EXV and the lowest on day 3 $(8.06 \pm 0.65$ Trolox mmol/l) with Car (Fig. 5B). Antioxidant capacity, measured by the TEAC assay, showed significant differences between the control sample and samples on days 5, 14 and 21 for all enzyme preparations. The obtained results were in a good agreement with the previous study, focusing on the Croatian variety, Teran, macerated for 21 days, as well [38]. According to Villaño et al. [39], TEAC values more than 11 are considered very high. The highest TEAC values were obtained using EXV, ranging from $11.38 \pm 1.32$ (day 3) to 17.20 \pm 1.57 (day 10), expressed as Trolox (mmol/l; Fig. 5B). For Cabernet Sauvignon samples from Argentina, Lingua et al. [30] found a similar TEAC value $(12.8 \mathrm{mmol} / \mathrm{l})$ after alcohol fermentation, and Maletić et al. [40] reported TEAC values after 14 days of maceration for Babić (18.1 Trolox mmol/l) and Plavac mali (39.2 Trolox mmol/l), demonstrating that antioxidant capacity largely depends on variety.

\subsection{Influence of maceration time and enzyme preparation additions on TPC}

The experimental results demonstrated that prolonged maceration time yielded higher TPC, in accordance with the findings of Kocabey et al. [35], who reported increased TPC during macera- tion lasting 15 days. Obtained results indicate that TPC increased until day 21 for all wine samples macerated with different enzyme preparations (EXV, CP and Car; Fig. 6). The highest values of TPC among all other samples were observed in wines produced with EXV enzyme preparation, which possesses pectolytic activity. In those wines, on day 21 of maceration, a TPC value of $1175.00 \pm$ $60.75 \mathrm{mg}$ GAE/l was determined, which was the highest value obtained in this study. According to Sacchi et al. [41], early reports on the effect of pectinases demonstrated an increase in color and TPC at the end of fermentation with Grenache, Carignane, Zinfandel, and Petite Sirah. Our experimental results indicated that extraction dynamics of phenolic compounds during alcoholic fermentation were exponential (Fig. 6). The maximum extraction rate in samples produced with enzyme preparation Car was achieved on day 7 of maceration with a TPC of $721.9 \mathrm{mg}$ GAE/l. Enzyme preparations $\mathrm{CP}$ and EXV showed maximum extraction on day 5 with TPC values of 609.41 and 652.71 mg GAE/l, respectively. These values are similar to those presented in literature, reporting a continuous increase of proanthocyanidins over days 15 to 19 in wines of grape variety Blaufränkisch, while longer contact led to some losses (low and high molecular weight proanthocyanidins increased up to day 19) [42].

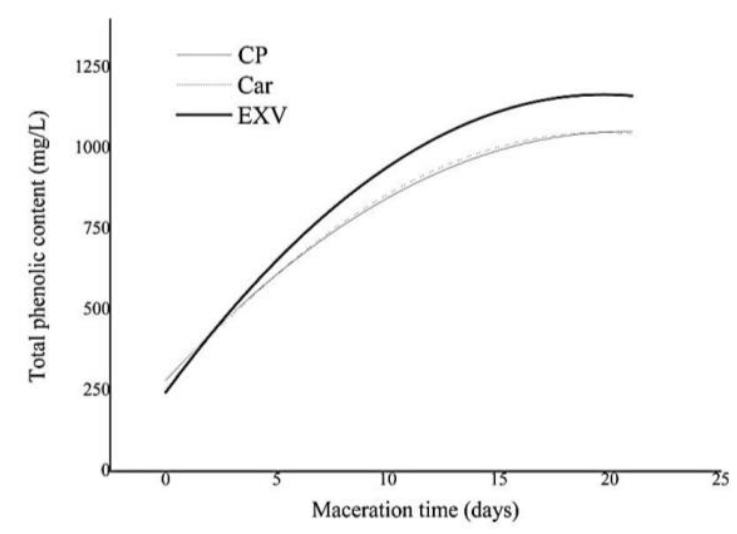

Fig. 6. Extraction dynamics of TPC over 21 days of maceration

Another study on the Teran variety showed that the highest TPC, flavonoid, and non-flavonoid contents were achieved on day 17 of skin maceration, which was conducted during five different periods (3, 7, 12, 17 and 21 days) [38]. Literature data indicated increasing TPC at the end of fermentation for Cabernet Sauvignon and Isabel wines produced with enzyme preparation treatment, while such behavior was not observed from wines made from Syrah [41]. Comparing TPCs of 
a control wine sample and enzyme treated samples, a significant statistical difference $(p<0.01)$ is highlighted. These results were in accordance with previous investigations, confirming that the TPC, flavonoid and non-flavonoid contents increased during prolonged skin contact periods [25].

\section{CONCLUSION}

The results presented in this study highlighted that kinetic extraction of phenolic compounds during alcoholic fermentation was greatly affected by maceration time and the addition and kinetics of enzyme preparations. The highest extraction rates were observed for catechin (EXV and $\mathrm{CP}$ ) and $p$ hydroxybenzoic acid (Car). According to extraction time of the analyzed phenolic compounds, maximam values were obtained at the end of day 15 for maceration with the addition of enzyme preparation $\mathrm{CP}$, with exceptions of gallic acid, catechin, and myricetin. Those compounds required longer maceration times for maximum extraction, which was increased by using enzyme preparations. Longer maceration times increased antiradical and antioxidant properties of wines, while the addition of enzyme preparation EXV showed the highest value for TPC.

Acknowledgements. This work was supported by the Scientific Research Grant from the Ministry of Education, Science, and Technological Development of the Republic of Serbia (No TR31020) and agreement No 451-03-68/2020-14/200161.

\section{REFERENCES}

[1] V. Maraš, T. Košmerl, V. Kodžulović, S. Šućur, A. Savović, M. Perišić, Yield and oenological potential of Montenegrin autochthonous grape varieties 'Kratošija' and 'Žižak', J. Hyg. Eng. Des., 8, 158-162 (2014).

[2] A. P. Nel, Tannins and anthocyanins: from their origin to wine analysis - a review, South African J. Enol. Vitic., 39 (1), 1-20 (2018).

DOI: http://dx.doi.org/10.21548/39-1-1503.

[3] C. Ghanem, P. Taillandier, Z. Rizk, N. Nehme, J. P. Souchard, Y. El Rayess, Evolution of polyphenols during syrah grapes maceration: time versus temperature effect, Molecules, 24, 2845 (2019).

DOI: https://doi.org/10.3390/molecules24152845

[4] N. López, E. Puértolas, P. Hernández-Orte, I. Álvarez, J. Raso, Effect of a pulsed electric field treatment on the anthocyanins composition and other quality parameters of Cabernet Sauvignon freshly fermented model wines obtained after different maceration times, $L W T-$ Food Sci. Technol., 42, 1225-1231 (2009).

DOI: https://doi.org/10.1016/j.lwt.2009.03.009

[5] J. Garrido, F. Borges, Wine and grape polyphenols - A chemical perspective, Food Res. Int., 54, 1844-1858 (2013). DOI: https://doi.org/10.1016/j.foodres.2013.08.002.

[6] L. R. Silva, M. Queiroz, Bioactive compounds of red grapes from Dão region (Portugal): Evaluation of phe- nolic and organic profile, Asian Pac. J. Trop. Biomed., 6, 315-321 (2016).

DOI: https://doi.org/10.1016/j.apjtb.2015.12.015

[7] P. B. Shi, T. X. Yue, L. L. Ai, Y. F. Cheng, J. F. Meng, M. H. Li, Z. W. Zhang, Phenolic compound profiles in grape skins of Cabernet Sauvignon, Merlot, Syrah and Marselan cultivated in the Shacheng Area (China), South African J. Enol. Vitic., 37, 132-138 (2016). DOI: https://doi.org/10.21548/37-2-898

[8] Lj. Gojkovic-Bukarica, J. Markovic-Lipkovski, H. Heinle, S. Cirovic, J. Rajkovic, V. Djokic, V. Zivanovic, A. Bukarica, R. Novakovic, The red wine polyphenol resveratrol induced relaxation of the isolated renal artery of diabetic rats: The role of potassium channels, $J$. Funct. Foods, 52, 266-275 (2019).

DOI: https://doi.org/10.1016/j.jff.2018.11.009

[9] U. Cakar, N. Grozdanic, A. Petrovic, B. Pejin, B. Nastasijevic, B. Markovic, B. Dordevic, Fruit wines inhibitory activity against $\alpha$-glucosidase, Curr. Pharm. Biotechnol., 18, 1264-1272 (2017).

DOI: https://doi.org/10.2174/1389201019666180410112439

[10] T. Košmerl, L. Bertalanič, V, Maraš, V. Kodžulović, S. Šućur, H. Abramovič, Impact of yield on total polyphenols, anthocyanins, reducing sugars and antioxidant potential in white and red wines produced from Montenegrin autochthonous grape varieties, Food Sci. Technol., 1 (1), 7-15 (2013). DOI: 10.13189/fst.2013.010102

[11] H. Kelebek, A. Canbas, S. Selli, Pectolytic enzyme addition on the anthocyanin, J. Food Process. Preserv., 33, 296-311 (2008).

[12] N. El Darra, M. F. Turk, M. A. Ducasse, N. Grimi, R. G. Maroun, N. Louka, E. Vorobiev, Changes in polyphenol profiles and color composition of freshly fermented model wine due to pulsed electric field, enzymes and thermovinification pretreatments, Food Chem., 194, 944-950 (2016). DOI: https://doi.org/10.1016/j.foodchem.2015.08.059

[13] M. Ljekočević, M. Jadranin, J. Stanković, B. Popović, N. Nikićević, A. Petrović, V. Tešević, Phenolic composition and DPPH radical scavenging activity of plum wine produced from three plum cultivars, J. Serb. Chem. Soc., 84 (2), 141-151 (2019). DOI: https://doi.org/10.2298/JSC180710096L

[14] I. F. F. Benzie, J. J. Strain, The ferric reducing ability of plasma (FRAP) as a measure of "antioxidant power": the FRAP assay, Anal. Biochem., 239, 70-76 (1996). DOI: doi.org/10.1006/abio.1996.0292

[15] H. Abramovič, B. Grobin, N. Poklar Ulrih, B. Cigić, relevance and standardization of in vitro antioxidant assays: ABTS, DPPH and Folin-Ciocalteu, J. Chem. (2018). DOI: doi.org/10.1155/2018/4608405

[16] T. Košmerl, B. Cigić, Antioxidant potential and phenolic composition of white and red wines, Le Bulletin de l'OIV: revue technique international, 81, 251-259 (2008).

[17] L. Bertalanič, T. Košmerl, N. Poklar Ulrih, B. Cigić, The influence of solvent composition on antioxidant potential of model polyphenols and red wines determined with DPPH, J. Agric. Food Chem., 60 (50), 1-28 (2012). DOI: $10.1021 / \mathrm{jf3041512.}$

[18] U. Čakar, A. Petrović, M. Živković, V. Vajs, M. Milovanović, J. Zeravik, B. Đorđević, Phenolic profile of some fruit wines and their antioxidant properties, Hem. Ind., 70 (6), 661-672 (2016). DOI: 10.2298/HEMIND150722002C. 
[19] R. Re, N. Pellegrini, A. Proteggente, A. Pannala, M. Yang, C. Rice-Evans, Antioxidant activity applying an improved ABTS radical cationde decolorization assay, Free Radic Biol Med., 26, 1231-1237 (1999). DOI: https://doi.org/10.1016/S0891-5849(98)00315-3

[20] H. Tanner, H. R. Brunner, Gentranke-Analytik, Verlag Heller Chemie und Verwaltunsgesellschaft mbH, Germany, 1979.

[21] H. Abramovič, T. Košmerl, N. Poklar Ulrih, B. Cigić, Contribution of $\mathrm{SO}_{2}$ to antioxidant potential of white wine, Food Chem., 174, 147-153 (2015). DOI: doi.org/10.1016/j.foodchem.2014.11.030.

[22] N. Poklar Ulrih, R. Opara, M. Skrt, T. Košmerl, M. Wondra, V. Abram, Part I. Polyphenols composition and antioxidant potential during 'Blaufränkisch' grape maceration and red wine maturation, and the effects of transresveratrol addition, Food Chem. Toxicol., 137, 111-122 (2020). DOI: doi.org/10.1016/j.fct.2020.111122

[23] N. Francesca, R. Romano, C. Sannino, L. Le Grottaglie, L. Settanni, G. Moschetti, Evolution of microbiological and chemical parameters during red wine making with extended post-fermentation maceration, Int. J. Food Microbiol., 171, 84-93 (2014).

DOI: https://doi.org/10.1016/j.ijfoodmicro.2013.11.008

[24] E. Gómez-Plaza, R. Gil-Muñoz, J. M. López-Roca, A. Martínez-Cutillas, J. I. Fernández-Fernández, Phenolic compounds and color stability of red wines: effect of skin maceration time, Am. J. Enol. Vitic., 52, 266-270 (2001).

[25] V. Kovac, E. Alonso, M. Bourzeix, E. Revilla, Effects of several enological practices on the content of catechins and proanthocyanidins of red wines, J. Agric. Food Chem., 40, 1953-1957 (1992).

DOI: https://doi.org/10.1021/jf00022a045

[26] A. A. Borazan, B. Bozan, The influence of pectolytic enzyme addition and prefermentative mash heating during the winemaking process on the phenolic composition of Okuzgozu red wine, Food Chem., 138, 389-395 (2013). DOI: https://doi.org/10.1016/j.foodchem.2012.10.099

[27] U. Čakar, N. Grozdanić, B. Pejin, V. Vasić, M. Čakar, A. Petrović, B. Đorđević, Impact of vinification procedure on fruit wine inhibitory activity against alphaglucosidase, Food Biosci., 25, 1-7 (2018). DOI: $10.1016 /$ j.fbio.2018.06.009.

[28] B. Sun, A. C. Neves, T. A. Fernandes, A. L. Fernandes, N. Mateus, V. De Freitas, C. Leandro, M. I. Spranger, Evolution of phenolic composition of red wine during vinification and storage and its contribution to wine sensory properties and antioxidant activity, J. Agric. Food Chem., 59, 6550-6557 (2011). DOI: https://doi.org/10.1021/jf201383e.

[29] V. Ivanova-Petropulos, S. Durakova, A. Ricci, G. P. Parpinello, A. Versari, Extraction and evaluation of natural occurring bioactive compounds and change in antioxidant activity during red winemaking, J. Food Sci. Technol., 53, 2634-2643 (2016). DOI: https://doi.org/10.1007/s13197-016-2235-7

[30] M. S. Lingua, M. P. Fabani, D. A. Wunderlin, M. V. Baroni, From grape to wine: Changes in phenolic composition and its influence on antioxidant activity, Food Chem., 208, 228-238 (2016).

DOI: https://doi.org/10.1016/j.foodchem.2016.04.009
[31] J. M. Cvejic, S. V. Djekic, A. V. Petrovic, M. T. Atanackovic, S. M. Jovic, I. D. Brceski, L. C. GojkovicBukarica, Determination of trans- and cis-resveratrol in Serbian commercial wines, J. Chromatogr. Sci., 48, 229-234 (2010). DOI: https://doi.org/10.1093/chromsci/48.3.229

[32] P. Ribereau-Gayon, Y. Glories, A. Maujean, D. Dubourdieu, Handbook of Enology, Volume 2. The Chemistry of Wine Stabilization and Treatments (2nd ed.), Chapter 6 Chichester, John Wiley \& Sons, Ltd., (2006).

[33] D. Raičević, Z. Božinović, M. Petkov, V. IvanovaPetropulos, V. Kodžulović, M. Mugoša, S. Šućur, V. Maraš, Polyphenolic content and sensory profile of Montenegrin Vranac wines produced with different oenological products and maceration, Maced. J. Chem. Chem. Eng., 36 (2), (2017). DOI: $10.20450 /$ mjcce.2017.1145

[34] C. Pastore, G. Allegro, G. Valentini, E. Muzzi, I. Filippetti, Anthocyanin and flavonol composition response to veraison leaf removal on Cabernet Sauvignon, Nero d'Avola, Raboso Piave and Sangiovese Vitis vinifera L. cultivars, Sci. Hortic., 218, 147-155 (2017). DOI: https://doi.org/10.1016/j.scienta.2017.01.048

[35] N. Kocabey, M. Yilmaztekin, A.A. Hayaloglu, Effect of maceration duration on physicochemical characteristics, organic acid, phenolic compounds and antioxidant activity of red wine from Vitis vinifera L. Karaoglan, J. Food Sci. Technol., 53, 3557-3565 (2016). DOI: https://doi.org/10.1007/s13197-016-2335-4

[36] U. Čakar, A. Petrović,B. Pejin, M. Čakar, M. Živković, V. Vajs, B. Đorđević, Fruit as a substrate for a wine: A case study of selected berry and drupe fruit wines, Sci. Hortic., 244, 42-49 (2019). DOI: https://doi.org/10.1016/j.scienta.2018.09.020

[37] D. Di Majo, M. La Guardia, S. Giammanco, L. La Neve, M. Giammanco, The antioxidant capacity of red wine in relationship with its polyphenolic constituents, Food Chem. 111, 45-49 (2008). DOI: 10.1016/j.foodchem.2008.03.037

[38] K. Damijanić, M. Staver, K. Kovačević Ganić, M. Bubola, I. Palman, Effects of maceration duration on the phenolic composition and antioxidant capacity of "Teran" (Vitis vinifera L.) wine, Agric. Conspec. Sci., 77, 103-107 (2012).

[39] D. Villaño, M. S. Fernández-Pachón, A. M. Troncoso, M. C. García-Parrilla, Influence of enological practices on the antioxidant activity of wines, Food Chem., 95, 394-404 (2006).

DOI: https://doi.org/10.1016/j.foodchem.2005.01.005

[40] E. Maletić, J. K. Kontić, D. Preiner, A. Jeromel, C. D. Patz, H. Dietrich, Anthocyanin profile and antioxidative capacity of some autochthonous Croatian red wines, $J$. Food Agric. Environ., 7, 48-51 (2009).

[41] K. L. Sacchi, L. F. Bisson, D. O. Adams, A review of the effect of winemaking techniques on phenolic extraction in red wines, Am. J. Enol. Vitic., 56, 197-206 (2005).

[42] U. Vrhovsek, A. Vanzo, J. Nemanic, Effect of red wine maceration techniques on oligomeric and polymeric proanthocyanidins in wine, cv. Blaufränkisch, Vitis, 41 (1), 47-51 (2002) 